\title{
A FÖLDRAJZ JELENTŐSÉGE A 21. SZÁZAD MULTIPOLÁRIS VILÁGRENDJÉBEN
}

\section{THE POWER OF GEOGRAPHY IN THE MULTIPOLAR WORLD ORDER}

\author{
Csizmadia Norbert \\ elnök, Pallas Athéné Innovációs és Geopolitikai Alapítvány, társelnök, Magyar Földrajzi Társaság Geopolitikai Szakosztály, \\ mesteroktató, Budapesti Corvinus Egyetem, PhD-hallgató - Pécsi Tudományegyetem Földtudományi Doktori Iskola \\ csizmadia.norbert@paigeobudapest.hu
}

\begin{abstract}
ÖSSZEFOGLALÁS
Ez a tanulmány jelen világunk globális, szociális és földrajzi folyamatait vizsgálja meg. „Geofúziós" térképek segítségével kalauzolja el az olvasókat a 21. század globális világában a kor nyertes nemzetei, közösségei, vezetői és hatalmai vendégeként. A tanulmány többek között azt a megállapítást fedi fel, hogy ennek a századnak a tudósai (jelen esetben a felfedezők, geostratégák) határozzák meg azokat az irányelveket, amelyek segíthetnek minket formálódó új világunk globális társadalmi és gazdasági kihívásaival szemben. Ehhez azonban új térképekre van szükség, amelyek nem nélkülözik a régiek bölcsességét és használhatóságát, de a tudás új struktúrájával egészülnek ki. Az utóbbi időben felfedezett földrajzi és gazdasági összefüggések segítségével a tanulmány megpróbálja előre jelezni a globális folyamatokat. A módszertan a világ számos közelmúltban keletkezett felmérés és elemzés eredményeit veti össze geostratégiai, kulturális, földrajzi, társadalmi és gazdasági témákban, és ülteti azokat a globális hálózatba. A szerző tehát a tanulmány eredményeként bemutatja a 21. század új globális térképét, és egy többéves tanulmány eredményeit kínálja az olvasó számára segítségül, hogy el tudjanak igazodni ebben az új, változó világban.
\end{abstract}

\section{ABSTRACT}

The paper is based on a thorough investigation regarding the recent global, social and geographical processes. This 'Geofusion' guides the audience with the help of maps in the global world of the $21^{\text {st }}$ century through the quest for the winning nations, communities, leaders and powers of this age. The findings of the study include a significant recognition that the scientists who are taken as explorers, geostrategists of this century in this case, are expected to present

\footnotetext{
${ }^{1}$ A tanulmány Csizmadia Norbert (2018): Geofusion-Mapping of the 21st Century. A földrajz jelentősége a 21. század multipoláris világrendjében címủ könyvfejezetének rövidített és átdolgozott változata. In: Nováky E. - S. Gubik A. (szerk.): A múltból átívelö jövő - VIII. Magyar (Jubileumi) Jövökutatási Konferencia. 50 éves a magyar jövőkutatás, 2018. Budapest, 2018. november 14-25. Konferenciakötet. Győr: Palatia Kiadó és Nyomda, 67-74.
} 
guidelines of our new world full of global social and economic challenges. To do so, new maps are needed which do not miss the wisdom and tools of the old, but complement them with the new structure of knowledge. Using the lately discovered geographic and economic interrelations the study tries to give a prognosis of the global processes. The methodology contains the survey and analysis of many recent publications worldwide, regarding geostrategic, cultural, geographical, social, and economic surveys structured into global networks. In conclusion the author presents the result of the study which is a collage of the global map of the $21^{\text {st }}$ century as mentioned above. In summary this study displays the results of a several-year-long study giving the audience an image how economic navigation tools can help the investors and travellers to get along in the changing new world.

Kulcsszavak: földrajz, fúzió, geoökonómia, geopolitika, új világrend

Keywords: geography, fusion, geo-economy, geopoliticsh, new world order

\section{ÚJ MULTIPOLÁRIS VILÁGREND - A FÖLDRAJZ ÚJRAFELFEDEZÉSE}

Milyenek a 21. századi térképeink? Hogyan változott meg a világunk ebben a 21. századi új világrendben? Milyen szerepe van Kelet-Közép-Európának a világ geopolitikai térképén? Miért fontos az, hogy a 21. század aktuális globális gazdasági és politikai változásait a földrajzon keresztül érthessük meg? Egy új világrend hajnalán vagyunk. Amíg 1980-2010 között a globalizáció volt a meghatározó, addig a 2008-as gazdasági válság hatására új együttműködések, új szereplők, új gondolkodási formák, új megoldások, új értékrendek kezdtek kialakulni. 2010-től a globalizáció új korszakába lépett a technológia - a tudás korszakába.

Ebben az új korszakban a földrajz és a gazdaságföldrajz felemelkedéséröl beszélünk, a geopolitikai folyamatokat a geoökonómiai folyamatok váltják fel, a területszerzés helyett a piacokért folyik a verseny. Hálózatok és fúziók korában élünk. Ebben az összekapcsolt világban a komplex megközelítés válik a legfontosabbá. A világgazdaság pólusa ismét kelet felé tolódik, és amíg a 19. század a Brit Birodalom korszaka, a 20. század Amerika korszaka volt, a 21. század egyértelmúen Eurázsia évszázada lesz, Ázsia és az eurázsiai kontinens felelmélkedéséé, amelyen belül Kína vezető szerepet fog játszani. Az eddig ütközőzónaként aposztrofált kelet-közép-európai térség pedig az eurázsiai kontinens kaputérségévé válik az Új Selyemút nyugati kapujaként az EU legfejlettebb régióit tartalmazó technológiavezérelt Baden-Württenberg, Lombardia Bajorország keleti kapujaként és az egykori ókori római Borostyánút (ahol ma Kelet-Közép-Európa legfontosabb autóipari beruházásait találjuk) középső részeként. Kelet-Közép-Európa találkozó- és kapcsolódási pontja Nyugat és Kelet között egy hosszú távú, fenntartható Eurázsiai szuperkontinens részeként (Csizmadia, 2016). 
A 21. században a kapcsolódási pontok rendkívül fontosak (Barabási, 2003). A földrajz, a geoökonómia, a geopolitika és a globális gazdaság összekapcsolódásával komplexen szemlélhetjük a világunkat. Ebben a fúziós korszakban arra keressük térképek és a földrajz segítségével a választ, hogy kik lesznek ennek a korszaknak a nyertes nemzetei, közösségei, vezetöi? Hogyan érthetjük meg a körülöttünk zajló globális politikai fölrajzi, gazdasági és gazdaságföldrajzi folyamatokat? Hogyan tudjuk újradefiniálni és egyáltalán újrarajzolni a térképeinket? Hogyan válnak az egykor periférián lévő területek ismét központokká? A 2008-as pénzügyi és gazdasági válság új világrendet, új értékrendet teremtett, új szereplőkkel, új együttmüködésekkel, új helyekkel, a korábbi centrumok kerültek perifériára, és a korábbi perifériák válhattak centrumokká. A korábbi receptek és dogmák megbuktak, újfajta gondolkodásmódra és módszerekre van szükségünk. A 21. század a tudás, a tehetség, a technológia és az innováció korszaka, amelynek valutája az egyedi ötlet és az innováció. A globalizáció korszaka után beköszöntött a technológia korszaka (Cséfalvay, 2017), és az egyik fö kérdés, hogy ebben a technológiavezérelt korszakban milyen szerepük lesz a helyeknek. Ez a tudás és a fúziók földrajza, a „geofúzió”, amely a komplex tudás és a földrajz találkozópontjává válik a hálózatok korában (Csizmadia, 2016).

\section{A FÖLDRAJZ A VILÁG MEGISMERÉSÉNEK ESZKÖZE}

A földrajz a világ megismerésének eszköze, hiszen a földrajz nemcsak a helyek memorizálása a térképeinken, hanem a földrajz ismerete és tudása magában hordozza a világ komplex megismerését. Nem mindenki gondolja persze így: Richard O'Brien a '90-es évek elején megírja $A$ globális pénzügyi integráció - a földrajz halála címü könyvét, amely a földrajzi térnek a globalizált világunkban betöltött szerepéröl szól (O’Brien, 1992). Szerinte a modern informatikának köszönhetően másodpercek alatt lehet dollármilliókat eljuttatni a Föld egyik sarkából a másikra. Nincs messze tehát az a jövő, amikor a ,gazdasági fejlődés szempontjából a földrajzi elhelyezkedés már nem számít tényezőnek". Nos, mára biztosan állíthatjuk, hogy O'Briennek nem lett igaza. Egy évtizeddel később a Stratford geopolitikai guruja, Robert D. Kaplan a globális folyamatokban a területiség meghatározó szerepének elismerését emeli fókuszba a The Revenge of Geography címü kötettel, amelyet O'Briennek adott válaszként is olvashatunk (Kaplan, 2013). Kaplan azt írja könyvében: lehet, hogy a földrajzi tényezők hatalmáról megfeledkezünk, de attól még nem szünnek meg. Még a technológiai fejlődés sem képes erre, bár sokan azt hitték. A technológiai fejlődés ugyanis nemcsak hogy nem hozta el a földrajz halálát, de újra felértékelte a földrajz jelentőségét. Hasonlóképpen vélekedik, egy picit más megközelítésben Thomas L. Friedman a Mégis lapos a Föld 
címủ nagyszerü könyv szerzője, aki 2013-ban azt mondta, hogy mai világunkban már nem fejlett és fejlődő országokról kell beszélnünk, hanem olyan országokról, amelyek képesek megmozgatni az emberek fantáziáját. Ezek az országok fognak számítani a jövőben.

\section{MIÉRT FONTOSAK A TÉRKÉPEK?}

Ahhoz, hogy megértsük ennek az új korszaknak a folyamatait, térképekre van szükségünk. A térképek fontosak! A térképek folyamatosan változnak, fejlödnek, de a jelentésük és a jelentöségük változatlan. A térképek fontosak voltak a múltban, fontosak a jelenben, és fontosak lesznek a jövőben is. De hogy is néz ki a mai világunk térképe? Mi az, amit láthatunk és leolvashatunk a térképekröl: országokat, amelyeket különböző színekkel jelölnek, országhatárokat, amelyek elválasztják az egyes országokat különböző színekkel, hogy jobban látszódjanak, kontinenseket és óceánokat. Ilyen a mai világ politikai térképe: közel kétszáz ország, öt kontinens, három nagy óceán. Ami még feltünhet a térképeinken, hogy mindig Európa van a közepükön. Mi európaiak, eurocentrikus világban élünk, és eurocentrikus világtérképen át látjuk a világot. A térképek azért is segítik az új gondolkodást, mert ha más szemszögből nézzük a világot, akkor újfajta nézőpont alakítható ki: hogy is néz ki a világtérképünk, ha Ázsia és a Csendes-óceán perspektívájából néznénk?

De képzeljük csak el, hogy néznének ki a térképeink, ha nem országokat rajzolnánk a világtérképünkre, hanem 182 repülőgép-társaság légi útvonalait vagy éppen a nemzetközi kutatási együttműködések és tudományos munkák eredményeit. Vagy éppen a kétmilliárd ember által használt Facebook kapcsolati térképét, mind-mind hálózatos térkép, vonalakkal, és a csomópontokban a találkozási pontok, amelyek kirajzolják a 21. század erővonalait és fő központjait, a városokat. És hogyan nézne ki a világtérképünk, ha országok helyett városokat ábrázolna országhatárok nélkül: a világon található legjelentősebb közel négyszáz város egymáshoz kapcsolódó hálózati térképét vagy épp a világ ötven legfontosabb repülőterét? A városok lakosságszámát és a városaink nagyságát, úgy jelölve, minél népesebb egy város, annál nagyobb pontként jelenik meg a térképen. Pont úgy, ahogy Benjamin Henning világtérképén, aki a Views of the World nevü internetes oldalán (URL1, URL2) teljesen újraalkotta a világtérképet. Abból indult ki, hogy egy adott kategóriában minél jelentősebb egy város vagy egy ország, annál jobban kidudorodik a térképből, így az általa alkotott világtérképek teljesen új színben mutatják be a Földünkön lezajló térbeli folyamatokat. Mint például a világ népesedési térképén.

A 21. század a tudás, a kreativitás évszázada, az egyéni ötletek és innovációk a legfontosabb valutái, és azok az országok, amelyek nem rendelkeznek elég 
tudással, kénytelenek lesznek megvásárolni azt, pedig a tudás egyre drágább és drágább lesz. A földrajz felemelkedésének vagyunk a szemtanúi, és különösen a gazdaság és a földrajz összekapcsolódásával kialakult geoökonómia válik egyre jelentősebbé. 2016 márciusában a Londoni Tacitus Lectures előadássorozat során megkérdezték a brit jegybank egykori alelnökét, Paul Tuckert, hogy mégis kik lesznek a 21. század nyertes országai, nemzetei, közösségei, vezetői? Azt válaszolta, hogy azok az országok, amelyek összehangoljak a pénzügyi, azaz a monetáris politikájukat, a gazdaságpolitikájukat és a geopolitikájukat (Tucker, 2016).

\section{A GEOÖKONÓMIA KORA}

A 21. század fontos geopolitikai eleme, hogy a korábbi egypólusú világból többpólusú, multipoláris világrend van kialakulóban. A geoökonómia - a közgazdaságtan, a társadalomtudományok és a földrajz fúziós találkozópontjaként - meghatározza a világgazdasági folyamatokat. Jelenleg a geoökonómia felemelkedésének vagyunk tanúi, egy olyan versenynek, amely a kereskedelem nyelvén, de a háború logikája szerint zajlik. A geopolitikai verseny átalakítja a globális gazdaságot, a globális erőviszonyokat és a kormányzást. A pénzügyi-gazdasági válság előtt a geopolitika inkább csak helyi szinten játszott szerepet, manapság azonban újra fellángoltak a nagyhatalmak közötti konfliktusok is.

Habár számos háború zajlik a világban Damaszkusztól Ukrajnáig, a legfontosabb csatatérnek manapság a gazdaság számít. A katonai csapások helyét átveszik a gazdasági szankciók, a katonai szövetségekét az egymással versenyző kereskedelmi rendszerek. A valutaháborúk valószínűsége ma sokkal nagyobb, mint a területfoglalásoké, illetve bizonyos nyersanyagok árának manipulálása (például az olajé) hatásosabbnak bizonyul, mint a konvencionális fegyverkezési verseny. A geoökonómia egyszerre jelenti a globalizáció antitézisét és a legnagyobb győzelmét is. Az országok kölcsönös függősége és összekapcsoltsága olyan méreteket ölt, hogy az ebből való kizárás lehetősége mindenki számára egy háborús konfliktus súlyával ér fel.

\section{ÖSSZEKAPCSOLTSÁG - AZ ÖSSZEKÖTŐ VONALAK FONTOSSÁGA}

A 21. század megismerésének térképén van még egy térképi elem, ami a határoknál is fontosabb: a helyeket és kontinenseket átívelő és összekötő vonalak. Ezek az infrastrukturális vonalak. Parag Khanna 2016. januári TED-es előadásában azt mondta, hogy van $500000 \mathrm{~km}$ határ, van 1 millió km hosszúságú tenger alatti internetkábel, 2 millió km hosszúságú gázvezeték, 4 millió km hosszúságú vasúthálózat és 64 millió km hosszúságú úthálózat. Ezek a hálózatok lesznek a 
legfontosabb vonalak a térképeinken. És nem véletlenül Kína hosszú távú geostratégiája, hogy hogyan lehet a szárazföldre visszahelyezni a világgazdaság tengelyét az óceánokról.

Az Új Selyemút vagy Övezet és Út kezdeményezést Kína 2013-ban indította el. Kína hosszú távú tervének lényege, hogy az Új Selyemút kiépítésével viszszaszerezze Eurázsia egykori történelmi, kulturális, gazdasági és kereskedelmi jelentőségét. Az Új Selyemút vasútvonalakból, tengeri és szárazföldi kikötők fejlesztéséből, autópálya-építésekből, logisztikai központok létesítéséből és fejlesztéséből áll. Hálózatokból, amelyek gazdasági folyosókon keresztül valósulnak meg. A program 2013-as meghirdetése óta kínai részről komoly pénzügyi befektetések és tervek születtek annak érdekében, hogy az új Eurázsiára kiterjedő gazdasági övezet valóban megvalósulhasson. A Kínai Fejlesztési Bank mintegy 1000 milliárd dollárt különített el több száz különféle projektre.

Az Új Selyemút keretében kiépülő infrastrukturális hálózatok főbb csomópontjai átrajzolják az egyes térségek jelentőségét is, és új központok jelennek meg. A Kazahsztánban található Horgos (Khorgos) szárazkikötő, amit a világ legnagyobb szárazkikötőjének is emlegetnek, és Kína legfontosabb szárazföldi útvonalának legfontosabb eurázsiai kapuja és fontos logisztikai központja, Kelet-Közép-Európa fejlődésére is hatással van. Ugyanúgy, ahogy a Kína-Pakisztán gazdasági folyosó, amely a világ legmagasabban fekvő burkolt nemzetközi útján a Karakoum Highway-en keresztül köti össze Kínát az Arab-tengerrel Gwadar kikötőjén keresztül. Gwadar jelentősége többek között abból áll, hogy rajta keresztül a kínai áruk gyorsabban érik el az európai kontinenst, mint a Malaka-szoroson áthaladó hagyományos szállítási útvonalak. Az áruk egyik fö elosztó központja a görög Pireusz kikötője, amelyből az áruk várhatóan a Belgrád-Budapest vasútvonalon érik el Magyarországot, és onnan továbbindulnak Rotterdam és Hamburg kikötői felé. Nem véletlen, hogy az Övezet és Út kezdeményezéshez eddig hatvannégy ország csatlakozott, és az sem véletlen, hogy Kína jelentős szerepet szán Magyarországnak az Új Selyemút megépítésével, egyszerre három selyemút-hálózat is találkozik Magyarországnál. Ezért hazánk az Új Selyemút egyik kulcsországa, a kelet-közép-európai térség pedig az új kaputérségévé válhat.

Az egykori Selyemút mindig is fontos volt a történelem során, négy birodalmat kötött össze, és az adott korszakok legfontosabb termékeit, technológiai újdonságait, innovációit és tudását szállította, és minőségi termékek cseréltek gazdát. A Selyemút nemcsak infrastrukturális hálózatokból, de tudásmegosztásból, az emberek közötti kapcsolatokból, kulturális és pénzügyi együttmüködésekből is áll. 2013-tól harmincnyolc kínai és harminchat európai város között összesen 3673 vonat közlekedik, ez több mint 180000 új munkahelyet teremtett. A pireuszi kikötő húsz nappal rövidítheti le a tengeri szállítás hosszát, a Hszian (Xian)Duisburg vasúti útvonalon pedig huszonnégy nap alatt ér oda az áru korábbi negyvenkét nap helyett. A vasúti közlekedés központjai a németországi Duisburg, 
a belorusz-lengyel határnál található Brest, a lengyelországi Łódź, a görög kikötő, Pireusz, valamint Budapest lehet. Ennek értelmében egy új fejlődési tengely alakul ki, amely északon kelet-nyugat, a déli ágon pedig ÉNY-DK irányú, amely Pireuszt kapcsolja össze Rotterdammal vagy éppen a hamburgi kikötővel. Ezáltal kialakul egy észak-déli övezet a Balti-tengertől az Adriáig, illetve a Fekete-tengerig, és az érintett 16+1 tagország az egyik fontos kapcsolatot jelenti Kínával. Nem véletlen, hogy a kínai elképzelések szerint ebben a térségben két központ alakul ki: az egyik az északi, Varsó központtal, amely főként a szállítás, a logisztikai, az energetikai befektetések, míg a déli sávban Budapest, amely a pénzügyi szolgáltatási kulturális és intellektuális együttműködések helyszíne.

\section{FÚZIÓK ÉS HÁLÓZATOK KORÁBAN ÉLÜNK}

A tudás korszakában élünk, a geoökonómia korában és egy fúziós világban. Fúziókat találhatunk a gasztronómiában, a zenében, a tudományban, az építészetben. A fúziók azért is fontosak, mert a legváratlanabb helyekről történő találkozásokból születik valami egészen új. A gasztrofúzióknál például azt mondják, akkor beszélünk fúzióról, amikor a Kelet találkozik a Nyugattal. És ebben a fúziós korszakban, ebben a geofúziós korszakban az adat (big data) lesz a 21. század nyersanyaga, a tudás, a kreativitás, az élmény, a szolgáltatás, új szereplőkkel és új együttmüködésből a kicsikből lesznek a nagyok, ahogy ezt a startup cégek, a startup városok és a startup nemzetek megmutatták.

A hálózatok összekapcsoltsága mellett legfontosabb összetevő a komplexitás mérése. A Massachusetts Institute of Technology (MIT) kutatói 2012-ben publikálták először a gazdasági komplexitás atlaszát. Ricardo Hausmann, aki 2017 júniusában Dublinban a Regional Studies Association (RSA) éves konferencián tartotta vitaindító előadását, bemutatta a kutatás legújabb eredményeit. A gazdasági komplexitás mérésének legfontosabb tényezői, hogy egy adott ország mit exportál, és maga az exportált termék hogyan kapcsolódik a globális terméktérbe. Hausmann szerint két dolog számít: az egyik a tudás és a magasan képzett munkaerő, a másik pedig maga az exportált termék, azaz hogy egy adott ország exportstruktúrájában minél nagyobb arányban szerepeljenek a magas hozzáadott értékü iparágak. Ebben az újfajta gazdasági komplex versenyképességben Japán a listavezetö, amelyet Németország követ, és a TOP-10 országokban három térségből szerepelnek országok: Délkelet-Ázsia (Korea, Szingapúr), a Skandináv országok (Finnország, Svédország, Norvégia), valamint a kelet-közép-európai országok (Magyarország, Ausztria, Csehország, Lengyelország és Szlovákia). Ezért is fontos, hogy a globalizáció új tudás és technológiai tudás korszakában minél magasabb legyen az innováció aránya, és az összekapcsoltság révén a térség a 21. század növekvő prosperáló térsége lehessen. 


\section{GEOMANIFESZTÓ - A FÖLDRAJZ FONTOSSÁGA ÉS FELEMELKEDÉSE A 21. SZÁZADBAN}

A 21. század döntéshozói azok lesznek, akik képesek geopolitikai látásmóddal szemlélni a világot, akik újra merik rajzolni a térképeket. A geopolitikai fordulópontok mögött végső soron mindig emberek és emberi döntések állnak. A 21. század döntéshozói, gazdasági, politikai, tudományos és technológiai vezetői pedig azok lesznek, akik képesek átlátni a globális összefüggéseket, és maguk köré formálni a kreativitás és információáramlás csomópontjait. Akik elég bátrak, kíváncsiak és kreatívak ahhoz, hogy eröt merítsenek a válságokból, és ahhoz, hogy újragondolják a térbeliség szerepét a globális döntéshozatalban. Azok, akik keresik a fúziót, az új határterületeket, legyenek azok fizikaiak, természetiek vagy tudományosak. Akik személyes hálózatokat építenek ki a többi kreatív hubbal, és erőt merítenek a kultúrák közötti tapasztalatcseréből. Ök lesznek a vérbeli felfedezők, a globális vezérek, a dinamikus térképek vándorai, akik geopolitikai látásmóddal felvértezve újraformálják a világot.

\section{IRODALOM}

Barabási A. L. (2003): Behálózva - a hálózatok új tudománya. Budapest: Magyar Könyvklub

Cséfalvay Z. (2017): A nagy korszakváltás. Budapest: Kairosz Könyvkiadó

Csizmadia N. (2016): Geopillanat, a 21. század megismerésének térképe. Budapest: L'Harmattan Kiadó

Ferguson, N. (2011): Civilization: The West and the Rest. London: Penguin Books

Florida, R. (2012): The Rise of the Creative Class. New York: Basic Books

Friedman, G. (2011): The Next Decade: Where We've Been ... And Where We're Going. New York: Anchor

Friedman, T. L. (2005): The World is Flat. New York: Farrar, Straus and Giroux

Glaeser, E. (2012): Triumph of the City: How Our Greatest Invention Makes Us Richer, Smarter, Greener, Healthier, and Happier. London: Penguin Books

Hausmann, R. - Hidalgo, C. A. et al. (2011): The Atlas of Economic Complexity. New Hampshire: Puritan Press, http://atlas.cid.harvard.edu/

Kaplan, R. D. (2013): The Revenge of Geography: What the Map Tells Us About Coming Conflicts and the Battle against Fate. New York: Random House

Khanna, P. (2008): The Second World: Empires and Influence in the New Global Order. New York: Random House

Khanna, P. (2016): Connectography-Mapping the Future of Global Civilization. New York: Random House

Khanna, P. (2019): The Future is Asian. New York: Simon \& Schuster

Kotkin, J. (1994): Tribes: How Race, Religion and Identity Determine Success in the New Global Economy. New York: Random House

Marshall, T. (2015): Prisoners of Geography: Ten Maps That Explain Everything About the World. New York: Scribner

Matolcsy Gy. (2015): Amerikai Birodalom - A jövö forgatókönyvei. Budapest: Pallas Athéné Geopolitikai Alapítvány 
O’Brien, R. (1992): Global Financial Integration: The End of Geography. London: Chatham House Szilágyi I. (2013): Geopolitika. Pécs: Publikon

Tucker, P. (2016): The Geopolitics of the International Monetary and Financial System. Tacitus Lecture 2016 - Worshipful Company of World Traders, London, 24 February 2016. http:// paultucker.me/wp-content/uploads/2018/04/The-Geopolitics-of-the-International-Monetary-and-Financial-System.pdf

Watson, R. (2009): Future Files: A Brief History of the Next 50 Years. London: Nicholas Brealey Publishing

URL1: viewsoftheworld.net/

URL2: https://images.app.goo.gl/kDnenT5HrsLeUkPz6 